\title{
Gunnar HarĐarson
}

\section{Hreinn hugur eða sannur maður?}

\section{Descartes um líkamlegar hliðar hugsunarinnar}

Einn pekktasti fulltrúi tvíhyggjunnar í vestrænni heimspekihefð er vafalítið franski 17. aldar heimspekingurinn René Descartes (1596-1650). Eins og margar fyrri gerðir tvíhyggju lýtur tvíhyggja hans einkum að greinarmun efnislegra hluta og mannlegrar hugsunar. Samkvæmt Descartes höfum við annars vegar efni sem hefur rúmtak og lýtur vélrœnum náttúrulögmálum og hins vegar hugsandi veru sem er hafin yfir lögmál efnisheimsins. Tengsl vitundar og efnis, sálar og líkama, verða býsna snúið vandamál í heimspeki Descartes, pví að rúmtakið er sérkenni efnisins, sem getur ekki hugsað, meðan bugsunin er sérkenni sálarinnar sem er ekki efnisleg. Hvernig ættu líkami og sál pá yfirleitt að geta haft áhrif hvort á annað? Er sjálfsveran kannski ekkert annað en hrein hugsun, aðgreind frá öllum líkamlegum hlutum? Descartes hefur iðulega verið túlkaður á pann hátt og gerður ábyrgur fyrir ýmsum kenningum sem oftar en ekki eru einfaldaðar úr hófi fram og liggja pá vel við gagnrýni eins og segja má að kristallist í bókartitli Antonio Damasio, Descartes' Error (Villa Descartes). ${ }^{2}$ Peirri staðreynd er miklu síður hampað

1 Um tvíhyggju almennt sjá til dæmis David Rosenthal, „Dualism“, The Shorter Routledge Encyclopedia of Philosophy, ritstjóri Edward Craig, London og New York: Routledge, 2005, bls. 200-204, eða Howard Robinson, „Dualism“, The Stanford Encyclopedia of Philosopby, ritstjóri Edward N. Zalta, á vefslóðinni https://plato. stanford.edu/archives/fall2017/entries/dualism/. Ég pakka Mikael M. Karlssyni, Sigríði Porgeirsdóttur og Birni Porsteinssyni fyrir að lesa pessa grein í handriti og benda mér á eitt og annað sem betur mátti fara. Einnig pakka ég ónafngreindum ritrýnum Ritsins fyrir góðar ábendingar sem ég hef reynt að taka tillit til. Af peim sökum er ekki við annan en höfundinn að sakast ef eitthvað pað sem hér er sagt reynist staðlausir stafir.

2 Antonio Damasio, Descartes' Error. Emotion, Reason and the Human Brain, London: Picador, 1994.

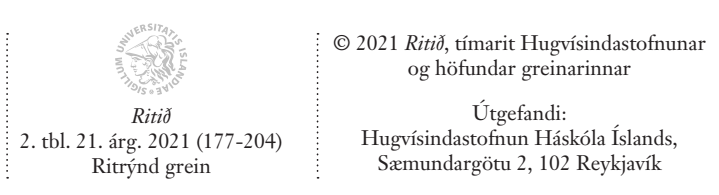

Birtist á vefnum http://www.ritid.hi.is. Tengiliður: ritið@hi.is

DOI: $10.33112 /$ ritid.21.2.9

Birt samkvæmt skilmálum Creative Commons BY (4.0). 
að Descartes heldur pví statt og stöðugt fram í ritum sínum að líkaminn og sálin séu „samslungin og ein heild“. ${ }^{3} \mathrm{Og}$ pað er einmitt athyglisvert: Descartes ræðir ekki bara um aðgreiningu sálar og líkama, heldur talar hann líka um einingu peirra. Ekki nóg með pað, heldur fjallar hann víða um líkamlegt eðli mannskepnunnar, ímyndunarafl, skynjun og tilfinningar, og ýmsar líkamlegar hliðar hinnar hugsandi veru sem hann fæst við með vísindalegri greiningu á gerð mannslíkamans og fyrirbærafræðilegri lýsingu, ef svo mætti kalla, á líkamlegri upplifun. ${ }^{4}$ Stundum er engu líkara en Descartes standi nær einhyggju - jafnvel efnishyggju - en tvíhyggju. Aðhylltist Descartes pá ekki kartesíska tvíhyggju? Hvernig fjallar hann um hugsun og líkama í ritum sínum? Pessar spurningar hafa verið mikið ræddar meðal fræðimanna og pótt tvíhyggjan hafi verið einna mest til umfjöllunar hafa fjölmargir heimspekingar á undanförnum árum beint sjónum að öðrum hliðum á hugsun Descartes um pessi efni. ${ }^{5}$ Í pessari ritgerð er ætlunin pó einungis að reifa nokkur atriði í skrifum Descartes um líkamlegar hliðar hinnar hugsandi veru, fyrst í Orðreðu um aðferð, par sem hann lýsir náttúruvísindalegum rannsóknum sínum á mannslíkamanum, síðan í Hugleiðingum um frumspeki, par sem hin hreina hugsun reynist fela í sér skynjun fyrir tilverknað líkamans, og loks í sendibréfum hans til Elísabetar prinsessu af Bæheimi par sem hugsun og líkami mynda, að pví er virðist, eina heild. ${ }^{6}$ Pótt Descartes hafi ávallt

3 René Descartes, Hugleiðingar um frumspeki, pýðandi Porsteinn Gylfason, Reykjavík: Hið íslenska bókmenntafélag, 2001, bls. 212.

4 Fyrirbærafræði (b. Phänomenologie) kom fram sem sérstök heimspekistefna á fyrri hluta 20. aldar með riti býska heimspekingsins Edmund Husserl, Logische Untersuchungen (1900-1901), sem rannsókn á gerð vitundarinnar út frá fyrstu persónu sjónarhorni, sbr. Dan Zahavi, Fyrirberafreði, pýðandi Björn Porsteinsson, Reykjavík: Heimspekistofnun - Háskólaútgáfan, 2008. Í pessari grein er hugtakið notað í almennri merkingu um ápekkar lýsingar Descartes í fyrstu persónu á upplifunum sínum af pví sem ber fyrir vitund hans.

5 Sjá til dæmis John Cottingham, Descartes, Oxford: Blackwell, 1986; Lilli Alanen, Descartes's Concept of Mind, Cambridge, Mass.: Harvard University Press, 2003; Jean-Luc Marion, Sur la pensée passive de Descartes, París: PUF, 2013; sjá einnig Sara Heinämaa, „Merleau-Ponty's dialogue with Descartes. The living body and its position in metaphysics“, Metaphysics, Facticity, Interpretation. Phenomenology in the Nordic Countries, ritstjórar Dan Zahavi, Sara Heinämaa og Hans Ruin, Kluwer Academic Publishers, 2003, bls. 23-48; sbr. Sara Heinämaa, „Eining líkama og sálar og kynjamismunur“, pýðandi Haukur Már Helgason, Hugur 17/2005, bls. 65-79. Sjá einnig Marleen Rozemond, Descartes's Dualism, Cambridge, Mass.: Harvard University Press, 1998, og Justin Skirry, Descartes and the Metaphysics of Human Nature, London: Continuum, 2005.

6 Í pessari grein nota ég orðalag, hugtök og heiti úr íslenskum býðingum rita Descartes. 
haldið tvíhyggju sinni til streitu, má sjá ýmsar dyr opnast í skrifum hans sem er kannski ekki fyllilega lokað sem möguleikum, pótt hann kanni pær hvorki nánar né fylgi peim eftir og sé jafnvel í afneitun um að hafa opnað pær.

\section{Efnishyggja i Orðreðu?}

Descartes var heimspekingur í hinni gömlu og víðu merkingu sem tíðkaðist pegar orðið „heimspeki“ var notað sem yfirhugtak um fjölmargar veraldlegar vísindagreinar: stærðfræðingur, eðlisfræðingur, náttúrufræðingur og líffærafræðingur, ekki síður en frumspekingur og pekkingarfræðingur. Á árunum 1629-1633 vann hann að samningu rits sem birti heildarsýn hans á heiminn og manninn, Le Monde (Heimurinn), en áætlaður annar hluti peirrar bókar fékk nafnið Traité de l'homme (Ritgerð um manninn). ${ }^{7}$ Pegar á hólminn var komið sá Descartes sig knúinn til að hætta við birtingu pessa rits árið 1633 til pess að sæta ekki ofsóknum á borð við pær sem Galíleó varð fyrir. Petta vísindarit, sem var hugsað sem syrpa ritgerða um viðfangsefnið, var skrifað á frönsku, væntanlega af sömu ástæðum og Descartes getur um í Orðrœðu um aðferð, sem gerði pað að verkum að hver sem læs var á frönsku, pótt ólærður væri að öðru leyti, átti að geta lesið bókina og kynnt sér hugmyndir pær og rannsóknir sem hún greindi frá. ${ }^{8}$ En Descartes lagði ekki árar í bát. Í staðinn fyrir að gefa út alla bókina sendi hann frá sér árið 1637 nokkur sýnishorn af peim rannsóknum sem hann hafði ætlað að birta í Heiminum og skrifaði sérstakan inngang að peim. Sá inngangur er Orðrœða um aðferð. Í peirri rit-

Önnur rit eftir hann, einkum pó Principia philosophiae [Lögmál heimspekinnar] (1644) og Les Passions de l'âme [Ástríður sálarinnar] (1649), sem og ýmis svör Descartes við andmælum við Hugleiðingarnar og bréfaskriftir hans til annarra heimspekinga, eru vitaskuld mikilvæg fyrir pessa umræðu og má finna nánari umfjöllun um pau í bókum og greinum sem vísað er til.

7 Ritgerðirnar voru gefnar út í París sem tvær bækur, Le Monde de Descartes ou Traité de la lumière (1662) og L'Homme de René Descartes et un Traité de la formation du foetus du mesme autheur (1664), sbr. René Descartes, The World and Other Writings, pýðandi Stephen Gaukroger, Cambridge: Cambridge University Press, 1998.

8 Descartes segist útlista rök sín „á mæltu máli“ í peirri von að „peir menn, sem ekki beita öðru en ómengaðri náttúrlegri skynsemi sinni, dæmi réttilegar um skoðanir mínar en hinir, sem trúa aðeins á fornar bækur“. Petta býðir að hver sem kann að lesa - eða hlusta á pað sem lesið er upphátt - á að geta skilið og fylgt eftir röksemdafærslum Descartes. Við erum öll hugsandi verur, búum yfir náttúrulegri skynsemi og eigum pess kost, fræðilega séð að minnsta kosti, að iðka hugleiðingar og stunda heimspeki. René Descartes, Orðræeða um aðferð, pýðandi Magnús G. Jónsson, Reykjavík: Hið íslenska bókmenntafélag, 1991, bls. 151. Hér eftir verður vísað til blaðsíðutala innan sviga í meginmáli. 
gerð gerir Descartes meðal annars grein fyrir eigin sýn á möguleika hinna nýju náttúruvísinda og tilgang peirra, og gerir pað reyndar líka í Principia philosophiae (Lögmál heimspekinnar) sem kom út nokkru síðar (1644) og inniheldur einnig margt af pví sem hann fjallaði um í Heiminum.

Orðreða um aðferð er einkar aðgengileg af vísindalegri aðferðafræðiritgerð að vera. Descartes er lipur stílisti og hefur tilfinningu fyrir bókmenntalegum áhrifamætti forms og rammafrásagna. Að forminu til er Orðreððan sjálfsævisaga par sem Descartes rekur bað sem á daga hans hefur drifið frá yngri árum og fram til pess tíma sem hann ritar bókina. Söguhetjan hefur pví stundum verið nefnd René en sögumaðurinn Descartes. ${ }^{9}$ Sjálfsærvisagan hefst reyndar á framsetningu skynsemishugtaksins sem hafði víðtækar afleiðingar í félagslegri heimspeki síðar meir pví að pað felur í sér að enginn munur sé á körlum og konum sem skynsemisverum. ${ }^{10}$ Descartes tekur síðan til við að segja frá aðferðinni sem hann hefur fundið til að „stýra“ skynsemi sinni. Hann hefur söguna pegar René gengur í skóla og rekur hvernig hann hafnar bóklegum lærdómi, hverri greininni á fæur annarri, enda er hinn bóklegi lærdómur dæmi um hvernig fyrri tíðar fræðimenn hafa beitt skynsemi sinni og flestir hafa gert einhver mistök í peim efnum. Fyrir vikið er allur sá fróðleikur sem geymdur er í bókasöfnum hæpinn. Heimspekin reynist til að mynda ekki annað en „listin að tala spaklega um hvaðeina og ávinna sér virðingu peirra sem minna vita“ (65). Eiginlega er pað aðeins stærðfræðin

9 Sjá til dæmis Mikael Karlsson, „Doubt, Reason, and Cartesian Therapy“, Descartes. Critical and Interpretative Essays, ritstjóri Michael Hooker, Baltimore og London: Johns Hopkins University Press, 1978, bls. 89-113, hér bls. 98; sbr. Mikael Karlsson, „Efi, skynsemi og kartesísk endurhæfing“, Hugur 27/2015, bls. 81-105, hér bls. 90; Jonathan Rée hefur sama hátt á í bók sinni, Philosophical Tales, London: Methuen, 1987, bls. 5-30.

10 Pótt allir einstaklingar séu gæddir sömu skynsemi eru peir mismunandi eftir pví hvað peir hafa til að bera af „góðum gáfum“: sumir hafa skjóta hugsun, frjótt ímyndunarafl, gott minni, en aðrir ekki, sbr. René Descartes, Orðrææða, bls. 62. Sjá ennfremur Konur í heimspeki nýaldar. Bréfaskipti og brot úr verkum. Elisabet af Beheimi, Damaris Cudworth Masham og Mary Astell, pýðandi Póra Björg Sigurðardóttir, Reykjavík: Hið íslenska bókmenntafélag, 2017, sbr. Póra Björg Sigurðardóttir, „'Osamsett vera sem kölluð er sál'. Femínískur lestur á frumspekilegum hugmyndum í bréfum Elísabetar af Bæheimi til René Descartes og Damaris Cudworth Masham til Gottfrieds Wilhelms Leibniz“, Hugur 22/2010, bls. 145-167; François Poullain de la Barre, Three Cartesian Feminist Treatises, pýðandi Vivien Bosley, Chicago og London: The University of Chicago Press, 2002; Genevieve Lloyd, Man of Reason. 'Male' and 'Female' in Western Philosophy, Minneapolis: University of Minnesota Press, 1984; Siep Stuurman, François Poulain de la Barre and the Invention of Modern Equality, Cambridge MA: Harvard University Press, 2004. 
sem situr eftir sem gagnlegt tæki til uppgötvunar óyggjandi sanninda. René ákveður pví að fara út í heiminn og kynna sér hvernig aðrir beita skynsemi sinni í aðstæðum sem kalla á ákvörðun par sem menn standa og falla með réttri beitingu skynseminnar í stað pess að geta velt vöngum í rólegheitum í hægindastólnum án pess að purfa að hafa neinar áhyggjur af mistökum (69).

Sem fyrr segir var Orðræðan hugsuð sem aðferðafræðilegur inngangur að sýnishornum af peim rannsóknum sem Descartes hafði tekið saman fyrir bók sína um Heiminn. Рað stóð hins vegar ekki til að ljóstra upp um pá afstöðu sem var rótin að pví að Descartes ákvað að birta ritið ekki í heild, pví að hún fól í sér sólmiðjukenninguna sem Galíleó hafði verið dæmdur í stofufangelsi fyrir. Descartes gætir pess pví vandlega að leyna raunverulegri skoðun sinni um petta efni í ritinu. Sýnishornin sem pað inniheldur eru Ljósfreðin (la Dioptrique) og Háloftafreðin (les Météores), auk Rúmfreðinnar (la Géométrie). En í Orðreðunni gefur hann samt sem áður heildarágrip af pví sem hann hafði skrifað í Heiminum og líkir aðferð sinni í peirri bók við aðferð listmálara: „Á flötu málverki getur hann ekki sýnt eins vel alla fleti á föstum hlut, og pess vegna velur hann einn aðalflöt og lætur hann horfa við birtunni. Hann hefur hina fletina í skugga og lætur pá ekki sjást, nema að pví leyti sem peir verða séðir, pegar horft er á aðalflötinn.“ (110) Pessari aðferð segist hann síðan hafa beitt í bókinni, sem heitir fullu nafni Heimurinn eða Ritgerð um ljósið:

Með pví að ég óttaðist að geta ekki komið fyrir í spjalli mínu öllu pví, sem ég hafði í huga, réðst ég einungis í að setja par rækilega fram skilning minn á ljósinu, og bæta síðan nokkru við um sólina og fastastjörnurnar, pví að paðan stafar næstum öllu ljósi; um himnana, af bví að peir koma ljósinu áleiðis; um reikistjörnur, halastjörnur og jörðina, par sem pær endurvarpa pví; og sér í lagi um alla jarðneska hluti, af pví að peir eru annað hvort litaðir, gegnsæir eða lýsandi; og að endingu um manninn, pví að hann sér ljósið. $(110-111)$

Maðurinn sér ljósið, hið efnislega ljós, og aðra hluti fyrir tilstuðlan pess. Рað birtist honum í vitund hans, ef svo má segja. Hvernig stendur á pví? Parna er vandinn sem Descartes glímdi við í frumspeki sinni kominn í hnotskurn: Hvert er samband vitundar og efnisveruleika? Reyndar hefur Descartes ekki einungis aðgang að hinu efnislega ljósi, heldur einnig að pví sem hann kallar „náttúrulegt ljós“ skilningsins sem gerir honum kleift að öðlast pekkingu 
á sjálfum sér og heiminum. ${ }^{11} \mathrm{Og}$ pað var einmitt efnisheimurinn, náttúran og maðurinn, sem voru upphaflega helsta viðfangsefni Descartes. Markmið hans var heildarskilningur á náttúrunni út frá vísindalegum forsendum og uppgötvun nýrrar og traustrar pekkingar sem unnt væri að nýta í págu mannkynsins, einkum hvað varðar verkfræði og læknisfræði, en hvor tveggja byggist á hugmyndum sem kenndar hafa verið við vélhyggju (133-134). ${ }^{12}$

Leiðin sem Descartes fer til pess að segja frá rannsóknum sínum felst í pví að fá lesandann með sér í pað sem kallast nú á dögum hugsunartilraun (sbr. e. thought experiment). Hann spyr „hvað verða mundi í nýjum heimi, ef Guð skapaði nú einhvers staðar í ímynduðu rúmi nógu mikið efni til að setja hann saman af" (111). Síðan lætur hann heiminn verða til úr óreiðu efnisins með aðstoð einfaldra lögmála náttúrunnar eða kannski öllu heldur kraftafræðinnar „sem eru hin sömu og náttúrunnar“ (124) og smám saman verða til jörðin, reikistjörnurnar, sólin og fastastjörnurnar. Jafnframt skýrir hann eðli ljóssins sem stafar frá stjörnunum og sólinni, hvernig pað berst um geiminn og milli hnatta og allt til jarðarinnar (112-113). Næst ræðir hann um jörðina, eðli hennar og gerð, svo og um einstaka pætti jarðarinnar, vatn og sjávarföll, höfin, fjöllin og jurtirnar. Síðan víkur hann að eldinum, sem gefur frá sér ljós, og ræðir ýmis áhrif hans og eiginleika, sem skipta máli fyrir pað sem síðar kemur án pess að lesandinn viti. Efnið og náttúrulögmálin nægja sem sé til pess að gera grein fyrir heiminum og tilurð hans. ${ }^{13}$

Loks tekur hann „til við að lýsa dýrum og sér í lagi mönnum“ (114). Og pá hefur hann sama hátt á og fyrr, hann býður upp á hugsunartilraun. Nú hugsar hann sér að Guð geri mannslíkama, „sem væri alveg eins og hver annar mannslíkami, bæði að ytri gerð lima sem innri gerð líffæra“ (115); pessi líkami er samansettur úr efni pví sem fyrir er, en pað sérkennir hann

11 René Descartes, Orðræða, bls. 90: „[...] pví að Guð hefur gætt hvern og einn nokkru ljósi, að hann megi greina rétt frá röngu [...]“, sbr. René Descartes, Hugleiðingar, til dæmis bls. 160 og 214.

12 Að vissu leyti má segja að hugsjónir Descartes hafi ekki orðið að veruleika fyrr en á 20. öld í mynd tæknilegra framfara hvað varðar samgöngur og mannvirki, og framfara í læknisfræði og lyfjaiðnaði. En auk pess sá Descartes siðfræðina sem pá grein sem mestu skipti fyrir lífshamingjuna og má ef til vill líta svo á að framfarir sem lúta að jöfnuði kynjanna og möguleika peirra til menntunar og vísindastarfa snerti pá hlið mála.

13 Descartes hélt pó ekki fram eindahyggju (atómisma), eins og sumir samtímamenn hans, pví að hann taldi að rúmtakið væri eðliseiginleiki efnisins og par með gat ekki verið til neitt tómarúm eins og bað sem atómkenningin gekk út frá; efnið væri pví óendanlega deilanlegt pótt pað tæki í raun á sig mynd smárra agna af mismunandi stærð og lögun. 
að hann er án sálar, ekki aðeins skynsemissálarinnar sem er hvort eð er aðgreind frá líkamanum og hefur pað eitt eðli að hugsa, heldur skortir hann líka „sálina sem gæðir lífi eða skyni“ (115) og jurtir og dýr (og par með maðurinn) voru talin hafa til að bera samkvæmt aristótelískri skólaspeki og áttu að standa undir næringu, hreyfingu og skynjun. ${ }^{14}$ Mannslíkaminn í hugsunartilrauninni hefur engin slík öfl til að bera, í staðinn koma vélræn lögmál náttúrunnar, og starfsemi hans er „öll hin sama og sú, sem segja má að sé mönnum og dýrum sameiginleg“ (115). Рað eina sem hann hefur er að „1́ hjarta hans væri einn pessi eldur án ljóss, sem ég hef pegar skýrt, og hef ekki getað skilið að væri annars eðlis en sá eldur, sem veldur hita í blauthirtu heyi eða gerjun í prúgusafa, pegar hann er látinn liggja á hratinu“ (115). Petta er eina forsendan sem Descartes gefur sér í hugsunartilrauninni, að pað sé hiti í hjartanu, af sama toga og allur annar hiti í nátturunni, sem knýr áfram líffærastarfsemina í mannslíkamanum:

Pegar ég hugði að peirri starfsemi, er leitt gat af slíku í pessum líkama, fann ég fyrir nákvæmlega alla pá starfsemi, sem farið getur fram í mönnum, án pess að hugsun komi til, og par af leiðandi án pess að sálin stuðli að henni. (115)

Petta hljómar satt að segja eins og hér tali efnishyggjumaður sem aðhyllist vísindalega smættarhyggju af einhverju tagi, enda er Descartes fljótur að bæta pví við að eðli sálarinnar, eða nánar til tekið, pess „hluta, sem aðgreindur er frá líkamanum“, sé „pað eitt að hugsa“. ${ }^{15}$ Líkaminn starfar sjálfvirkt á eigin forsendum samkvæmt náttúrulögmálunum og starfsemi hans er hin sama í mönnum jafnt sem dýrum. Að pessu leyti eru menn og dýr pá eins, pó að Descartes geri skarpan greinarmun á peim í öðru tilliti.

Til að útlista petta setur Descartes fram skýringu sína á starfsemi hjartans og æðanna. Hann lýsir hjartanu, gerð pess og starfsemi, tengslum pess við æðakerfið og virkni æðakerfisins, svo og tilurð og hlutverki „lífsandanna“ sem pjóta um taugakerfið til vöðvanna, sem í kjölfarið hreyfa líkamshlutana, og til heilans (116-125). Auk pess lætur Descartes pess getið að hann hafi „sýnt fram á, hver hlýtur að vera gerð tauga og vöðva mannslíkamans til pess, að lífsandarnir, sem í peim búa, hafi afl til pess að hreyfa líkamshlutana" (125).

14 Sjá einnig skýringargrein 59 í Orðreðunni, bls. 188-189.

15 Sbr. John Cottingham, „Cartesian Dualism“, The Cambridge Companion to Descartes, Cambridge: Cambridge University Press, 1992, bls. 245-246. 
Næst á eftir taugakerfinu víkur sögunni að heilanum. Eins og kunnugt er taldi Descartes að sálin og líkaminn tengdust einkanlega saman í köngurkirtlinum svonefnda, ${ }^{16}$ en hann er pó ekki til umræðu í Orðreðunni, heldur er par aðeins gefið stutt ágrip af starfsemi heilans:

Ennfremur benti ég á, hverjum breytingum heilinn hlýtur að taka til að valda vöku, svefni og draumum; hvernig ljós, hljóð, lykt, bragð, hiti og allir aðrir eiginleikar ytri hluta geta greypt í hann ýmislegar hugmyndir fyrir meðalgöngu skilningarvitanna; hversu hungur, porsti og aðrar innri kenndir geta einnig vakið par hugboð um sig. Ég benti einnig á, hvað líta beri par á sem allsherjarskyn, er tekur við pessum hugmyndum; sem minni, er varðveitir pær; og sem ímyndunarafl, er getur breytt peim ýmislega og sett saman nýjar og með pví að deila lífsöndunum til vöðvanna getur látið líkamshlutana hreyfast á jafnmargvíslegan hátt og líkamshlutar manna geta hreyfzt, án pess að viljinn eigi par hlut að, og koma pá jafnt til pær hreyfingar líkamans, sem verða fyrir áhrif ytri hluta á skilningarvitin, sem og fyrir innri kenndir, sem í honum eru. $(125-126)$

Hér fer fram mörgum sögum í senn, eins og segir í fornritunum. Svefn og vaka, jafnt sem draumar, eiga samkvæmt orðum Descartes rót að rekja til starfsemi heilans. Ytri hlutir - eða réttara sagt eiginleikar peirra, bæði skynrænir eiginleikar, pað er ljós, hljóð, lykt, bragð, hiti, og líka peir eiginleikar sem Descartes taldi viðfangsefni stærðfræðinnar, pað er form, lögun, pyngd og svo framvegis - prykkja í heilann „hugmyndir“ af ýmsu tagi. Petta býðir að heilinn hefur hugmyndir um ytri hluti og par með umhverfið og náttúruna, dýr, jurtir og annað fólk. ${ }^{17}$ Hefur hann pá vitund eða sjálfsvitund pótt hann

16 Ástæðan mun hafa verið sú, meðal annars, að sá kirtill er ekki samhverfur eins og heilahvelin og pví harla einstæður í samhengi sínu. Hann var bví talinn gegna einhverju sérstöku hlutverki samkvæmt peirra tíma læknisfræði. Í Ritgerð um manninn staðsetur Descartes allsherjarskynið og ímyndunaraflið í köngurkirtlinum en minnið raðast par í kring. Sálin tengist köngurkirtlinum með sérstökum hætti vegna pess að allsherjarskynið, sem tengir saman boðin frá öllum skilningarvitum, er staðsett par.

17 Раð er reyndar spurning hvað Descartes á hér við með hugtakinu „hugmynd“ (fr. idée). Hugsanlega ætti frekar að pýða idée hér sem „boð“ enda orðar Descartes pað svo að pessi fyrirbæri séu prykkt í heilann eða að pau séu send pangað. Um petta hugtak sjá John Cottingham, A Descartes Dictionary, Oxford: Blackwell, 1993, bls. 77-80. 
hafi ekki skynsemi? Pað er ekki alveg ljóst. Pegar um innra skyn ræðir, eru pað tilfinningar hungurs og porsta og aðrar innri kenndir og geðshræringar sem gefa sig til kynna hjá heilanum. Allsherjarskynið svonefnda, sensus communis, sem talið var hafa pað hlutverk að samhæfa ólíkar skynjanir, á sér einnig sinn stað í heilanum, nánar til tekið í köngurkirtlinum. Fyrir tilstilli lífsandanna getur heilinn síðan, með allri pessari starfsemi sinni, hreyft líkamann.

Af textanum að dæma verður ekki annað séð en að heilinn sjái um ýmislegt sem við teljum almennt til hugarstarfs. Prátt fyrir pað virðist Descartes ekki á pví að við hugsum með heilanum, og pað kemur reyndar í ljós stuttu síðar. ${ }^{18}$ Pótt heimurinn allur sé efnislegur og hugsaður í líkingu vélar og mannslíkaminn sé í grunninn ekki annað en „vél er gerð sé af meistara höndum“ (126) bendir Descartes á tvennt sem kemur í veg fyrir að hann haldi fram efnislegri einhyggju og vélhyggju um manninn sem heild. Petta tvennt er tungumálið og skynsemin. ${ }^{19}$ Ástæðan er sú að hann telur sig ekki geta gert grein fyrir peim á forsendum efnisins og starfsemi pess. Petta kemur á daginn pegar borin eru saman dýr og menn. Ólíkt manninum eru dýrin ekkert annað en vélar, pau eru án skynseminnar sem maðurinn er gæddur. Descartes segir sem svo að „væru til vélar, sem hefðu líffæri og ytri gerð apa eða einhverrar annarrar skynlausrar skepnu, pá væri mönnum alls ókleift að átta sig á, að pær væru ekki að öllu leyti sama eðlis og pau dýr eru“ (126). Petta atriði hefur reyndar farið mjög fyrir brjóstið á dýravinum. Ef dýrin eru ekkert nema vélar bregðast pau aðeins vélrænt við innra og ytra áreiti, en hafa engar ætlanir eða áform. ${ }^{20}$

En hvernig svo sem pessu er háttað með dýrin er pví ekki pannig farið með mennina: „Væru á hinn bóginn til vélar, sem líkar væru mannslíkama og líktu eftir athöfnum manna, eftir pví sem hagleikur leyfði, hefðu menn samt alltaf tvö óbrigðul ráð til að átta sig á, að pær væru alls ekki menn“ (126). Pessi tvö ráð eru í rauninni kennimörk sem hafa má til pess að sannreyna hvort um mann sé að ræða eða ekki, pví að vélin ræður ekki við pessi tvö at-

18 Sbr. Mikael Karlsson, „Hugsum við með heilanum?“, Hugur 7/1994-1995, bls. 134149, sbr. „Do We Think With Our Brains?“, Intellectica 53: 1/2010, bls. 67-94; sjá einnig Andy Clark og David Chalmers, „The Extended Mind“, Analysis 58: 1/1998, bls. $7-19$.

19 Мeð öðrum orðum pað sem grísku heimspekingarnir - og par með talinn Aristóteles - nefndu logos.

20 Sjá pó John Cottingham, „A Brute to the Brutes?'. Descartes' Treatment of Animals", Cartesian Reflections. Essays on Cartesian Philosophy, Oxford: Oxford University Press, 2008, bls. 163-172. 
riði. Descartes heldur áfram: „Hið fyrra er, að pær mundu aldrei geta notað orð né önnur tákn og tengt pau saman eins og menn gera til að tjá öðrum hugsanir sínar“ (126). Pær gætu sem sé ekki hugsað í hugtökum og miðlað skilningi sínum í máli og ræðu. ${ }^{21}$ Seinna atriðið er að athafnir vélanna gætu ekki verið „reistar á pekkingu, heldur væru bundnar líffæraskipan peirra“. Í dýrunum er pað „náttúran, sem [fer] sínu fram í peim samkvæmt skipan líffæra peirra: rétt eins og klukka, sem er ekki af öðru gerð en hjólum og fjöðrum ...“ en mannssálin, hins vegar, „verður ekki með neinu móti leidd af orku efnisins“ (129). Hún er pví ekki afsprengi líkamans heldur sérstök sköpun og samband hennar við líkamann er pví sérstaks eðlis. Descartes tekur parna hið margfræga dæmi af skipstjóranum eða „stýrimanni í skipi“ eins og hann orðar pað. Sálin er ekki tengd líkamanum með peim hætti, „nema pá til að hreyfa limi hans“ (129), segir Descartes í Orðrcðunni, heldur er hún miklu nátengdari honum. Рað verður að „tengja hana í líkamanum og sameina nánar, svo að til komi mannlegar tilfinningar og mannlegar hvatir og af verði sannur maður" (129). ${ }^{22}$ Hinn sanni maður er par með eitthvað annað en vél, jafnvel bótt lýsa megi líkamanum og skýra starfsemi hans með vísun til vélgengra náttúrulögmála í staðinn fyrir ,sálina sem gæðir lífi eða skyni“ (115); með öðrum orðum, pað er ekki hægt að smætta manninn niður í líkamann.

Með pessum hætti er manneskjunni lýst í Orðræðunni. Niðurstaðan sýnir takmarkanir vélhyggjuskýringa og jafnvel vísindalegrar nálgunar almennt. En eru pær takmarkanir endanlegar? Samkvæmt orðum Descartes sjálfs fer heilinn langt með að sjá um hugmyndir, skynjun og hreyfingu: hvers vegna ætti hann pá ekki líka að geta séð um hugsun og tungumál? „[L]jóst er, að ekki parf mikla skynsemi til að geta talað," segir Descartes meira að segja á einum stað (128). Maðurinn virðist samkvæmt pessu vera samsettur úr fágaðri efnisvél og anda. ${ }^{23}$ Líkaminn er sjálfvirk vél, pað parf enga hugsun til pess að bregðast við umhverfinu og hreyfa líkamann, heilinn er fullfær um pá hlið mála. Samt sem áður er sálin - væntanlega skynsemissálin - samofin líkamanum en tengist honum pó með sérstökum hætti í köngurkirtlinum. ${ }^{24}$

21 Í grein sinni, "The only sure sign...'. Thought and Language in Descartes“, Cartesian Reflections, Oxford: Oxford University Press, 2008, bls. 107-128, ræðir John Cottingham tengsl hugsunar og tungumáls í heimspeki Descartes.

22 Sbr. René Descartes, Hugleiðingar, bls. 219-221.

23 Sbr. Gilbert Ryle, "The Ghost in the Machine“, The Concept of Mind, London: Hutchinson, 1949.

24 Раð sem hér er tæpt á hefur verið nefnt „staðsetningarvandinn“ (e. the location problem), pað er að Descartes haldi pví fram að sálin sé bæði samofin líkamanum og 
Jafnframt á hún með einhverjum hætti að vera líkamanum æðri og stjórna honum með viljaathöfnum, sem purfa pá að grípa inn í suma pætti hinnar sjálfvirku vélar sem líkaminn er. Pegar Descartes talar um að sálin verði ekki leidd af „orku efnisins“ (129), á hann pá við að pað sé röklega ómögulegt að leiða sálina af möguleikum efnisins eða á hann við að pað sé vísindalega ógerlegt á grunni peirrar pekkingar sem samtími hans bjó yfir? Gæti pað verið hægt síðar? Descartes hafnar pví: „Af pessu leiðir, að í raun er óhugsandi, að nógu mörg ólík líffæri fyrirfinnist í einni vél, til að hún geti í öllum aðstæðum lífsins komið fram á sama hátt og skynsemin lætur menn gera“ (127). Vélin ætti pví ekki nema mjög takmarkaða möguleika til að bregðast við umhverfi sínu með hljóðum og atferli, hún væri bundin aðstæðunum, meðan mál og hugsun eigi par ótakmarkaða möguleika auk pess sem mennirnir búi yfir pekkingu og skilningi sem hefji athafnir peirra yfir aðstæður hverju sinni. En hvers vegna ætti fáguð vél, gerð af meistara höndum, ekki að geta ráðið við æðri hugsun? Sömu eða svipaðar spurningar leita á fræðimenn í gervigreindarfræðum nútímans. ${ }^{25}$ Ýmsir ritskýrendur eru reyndar á pví að Descartes hefði ekki getað hafnað pví að vísindaleg smættarhyggja gæti mögulega útskýrt skynsemissálina, ekki síður en jurtasálina eða dýrasálina, með náttúrulegri starfsemi líkamans eða heilans, pví að umfang smættunarinnar veltur að miklu leyti á möguleikum vísindalegrar athugunar. ${ }^{26}$

Snemma lék sá grunur á að tvíhyggja Descartes væri í raun ekkert annað en yfirvarp eða að hún segði að minnsta kosti ekki alla söguna: tvíhyggjan væri einfaldlega pægileg leið til að víkja sér undan ásökunum um efnishyggju og par með trúleysi, en petta tvennt var jafnan talið fara saman á pessum tíma. Aðeins væri eitt skref frá pví að segja að líkaminn pyrfti ekki sálina til að geta starfað til pess að segja að pað sem við köllum hugsun, sál og skynsemi væri smættanlegt í „orku efnisins“ (129). Ekki væri neinn eðlismunur á dýrum og mönnum, aðeins stigsmunur. Descartes sjálfur hafnaði pessu eindregið alla tíð, en sumir landar hans á 18. öld sáu ekki ástæðu til pess og urðu býsna umdeildir fyrir vikið. ${ }^{27}$ Í upphafi fimmta kafla Orðreðunnar segist

tengist honum á tilteknum stað, en parna virðist um tvær ólíkar hugmyndir að ræða; sbr. Margaret D. Wilson, Descartes, London og New York: Routledge, 1991, bls. 206 og 219.

25 Sbr. Veit efnið af andanum? Sjö fyrirlestrar um meðvitundina, ritstjórar Steinar Örn Atlason og Pórdís Helgadóttir, Reykjavík: Heimspekistofnun, 2009.

26 John Cottingham, „Cartesian Dualism“, bls. 252.

27 Til dæmis La Mettrie (1709-1751) í L'Homme machine (1747) og d'Holbach barón (1723-1789) í Système de la nature (1770). Efnishugtak La Mettrie er reyndar annað en hjá Descartes. 
Descartes ekki vilja „óvingast“ við lærða menn með pví að fjalla um „ýmsan vanda“ sem valdi deilum meðal peirra (109). Pótt hér eigi hann væntanlega við sólmiðjukenninguna er eins víst að sama gildi um vísindalega og læknisfræðilega umfjöllun um manninn og mannslíkamann. ${ }^{28}$ Í hinu vísindalega samhengi er til pess að líta, að með tvíhyggju sinni nær Descartes að undanskilja sálina (og par með skynsemina, siðferðið og trúna) frá náttúruvísindalegum rannsóknum, en á móti getur hann beitt öllum forsendum og aðferðum vísindanna á mannslíkamann og pannig lagt grunn að nýrri og vísindalegri læknisfræði. Markmiðið með rannsóknum hans var fyrst og fremst vísindaleg pekking á náttúrunni og manninum, í peim tilgangi að efla tæknilegar framfarir og læknisfræðilega pekkingu í págu mannkynsins. En frumspekilegar og trúarlegar afleiðingar peirrar pekkingar gátu hreyft við ýmsu sem talið var viðtekið og gátu jafnvel skoðast sem skaðlegar almenningi og trúarlegum stofnunum, eins og dæmið af Galíleó hafði sýnt.

\section{Hold i Hugleiðingum?}

Sé Orðreðan í grunninn vísindarit er málum á annan veg háttað í Hugleiðingunum. Pær eru reyndar bókmenntaverk, ekkert síður en Orðreðan, en rammi frásagnarinnar er að pessu sinni sá, að höfundurinn dregur sig í hlé í nokkra daga til pess að endurmeta forsendur skoðana sinna, og ritar á meðan dagbók par sem hann skráir hugrenningar sínar, eina á hverjum degi, í sex daga. Petta eru heimspekilegar hugleiðingar sem lýsa vegferð hugsuðarins frá efasemdum og óvissu til sjálfspekkingar og fullvissu, en snúast jafnframt um frumspekilegar og pekkingarfræðilegar forsendur hinna nýju náttúruvísinda. Segja má að Hugleiðingarnar séu eins konar sambland af frumspekilegri greiningu og fyrirbærafræðilegri lýsingu. Og ef áherslan liggur á eðlismun sálar og líkama í hinni frumspekilegu greiningu er pað í hinni fyrirbærafræðilegu lýsingu, sem beinist einkum að skynjuninni, sem við kynnumst hugmyndum Descartes um hið nána samband sálar og líkama.

28 Sbr. tvö bréf Descartes til Regiusar, par sem hann leggur til að Regius (1598-1679), sem var prófessor í læknisfræði við háskólann í Utrecht í Hollandi, noti frekar hugtök aristótelískrar skólaspeki en kerfi Descartesar sjálfs í fyrirlestrum sínum, til pess að skapa ekki úlfúð og vandræði við háskólann. Vere Chappell ræðir pessi bréf í grein sinni, „L'homme cartésien“ í Descartes. Objecter et répondre, ritstjórar Jean-Marie Beyssade og Jean-Luc Marion, París: PUF, 1994, bls. 403-426. Hann segir á bls. 411: „En fait, Descartes se révèle tout disposé à sacrifier la vérité à la convenance“ (Descartes virðist raunar alveg tilbúinn til pess að fórna sannleikanum fyrir hagræðið). 
Í Hugleiðingunum segir sögumaðurinn frá í fyrstu persónu og vísar pví til sjálfs sín með fyrstu persónu fornafninu „ég“ pegar hann útskýrir fyrir lesandanum frumspekileg hugtök og fyrirbærafræðilegar upplifanir, og lesandinn - sem sjálfur er einnig „ég“ - samsamar sig sögumanninum eða fylgir honum í humátt á eftir. ${ }^{29}$ Hvað er petta „ég“? Í stuttu máli er svarið „hugsandi vera“, res cogitans, vera sem býr yfir kennimarkinu „hugsun“. Eðli hinnar hugsandi veru opnast í leitinni að pví sem ekki verður með neinu móti dregið í efa. Jafnvel pótt skilningarvitin villi um fyrir manni og allt sé hugsanlega blekking, bæði líkami og sál, hlýt „ég“ að vera til, pví að annars væri enginn til að blekkja. Descartes rambar hér á pað sem síðar var nefnt hið forskilvitlega sjálf (e. transcendental subject) og var álitið skilyrði allrar reynslu. Hér er einnig til pess að líta að efarök Descartes varða ekki eingöngu tilvist líkamlegra hluta, heldur nær efinn einnig til sálarinnar: „Ég er ekki limabyggingin sem nefnd er mannslíkami. Ég er ekki eitthvert fínlegt loft sem leikur um pessa limi: vindur, logi, gufustrókur, blástur eða hvað sem ég kann að gera mér í hugarlund.“"30 Descartes getur pví hvorki samsamað sig líkama né sál á pessu stigi málsins. Pví verður pað hugsunin ein eða vitundin sem eftir stendur: „Hér verður sú staðreynd fyrir mér að til er hugsun; henni og henni einni verð ég ekki sviptur“ (144-145). Eftir svolitlar bollaleggingar dettur Descartes niður á eftirfarandi skilgreiningu: „Í pessum nákvæma skilningi er ég pví aðeins hugsandi vera, pað er að segja hugur, andi, skilningur, skynsemi - nú fyrst skil ég pessi orð“ (145). Segja mætti að viðfangsefnið sé nálgast út frá fyrirbærafræðilegri aðferð: settur er svigi utan um viðteknar hugmyndir og pví lýst sem fyrir vitundina ber. Pegar í ljós kemur að ekki er hægt að beita ímyndunaraflinu til að ákvarða nánar eðli hinnar hugsandi veru kemur Descartes með aðra og víðari skilgreiningu: „Hvað er ég? Hugsandi vera. Нvað er рað? Vera sem efast og skilur, játar og neitar, vill og vill ekki, ímyndar sér og skynjar“ (146). Pessi skilgreining takmarkast pví ekki við skynsemina eina. Hugsandi vera býr einmitt yfir ólíkum háttum hugsunar (lat. modi cogitandi), sem verða ekki með góðu móti aðgreindir frá henni; pað er sami hugurinn sem allir pessir hættir tilheyra:

Verður [eitthvað af pessu] aðgreint frá hugsun minni? Verður eitthvert peirra sagt óháð sjálfum mér? Рað er svo ljóst að pað er ég sem efast, skil og vil, að ég fæ ekki séð hvernig pað verður gert

29 Um fyrstu persónu sjónarhornið sjá Dan Zahavi, Fyrirberafreði, bls. 17-21.

30 René Descartes, Hugleiðingar, bls. 145. Hér á eftir er vísað til peirra innan sviga í meginmáli. 
ljósara. [...] Loks er pað ég sem skynja, pað er að segja virðist skynja líkamlega hluti með skilningarvitunum. Nú sé ég ljós, heyri hávaða, finn hita. Pessir hlutir eru ekki til, pví að ég er sofandi. En mér virðist ég að minnsta kosti sjá, heyra og finna til. Petta hlýtur að vera veruleiki, og bað eitt er réttilega nefnt skynjun. Að skynja í pessum nákvæma skilningi er ekki annað en að hugsa. (146-147)

Descartes er pví með að minnsta kosti tvær skilgreiningar á hugsandi veru í Hugleiðingunum - tvö hugtök um hana sem skarast en eru ekki alveg hin sömu. Samkvæmt síðara hugtakinu, en ekki hinu fyrra, eru ímyndun og skynjun fullgildir hættir hugsunar og hluti hinnar hugsandi veru ekkert síður en skilningur og vilji: ,jafnvel pótt pað sem ég skynja eða ímynda mér í hinum ytri heimi sé ekki til, pá eru til peir hættir hugsunarinnar sem ég kalla skynjanir og ímyndanir (að pví leyti sem skynjanir og ímyndanir eru hugsunarhættir og annað ekki).“ (155)

Hin hugsandi vera myndar andstæðu við líkama, res extensa, sem einkennist af pví að hafa rúmtak. Með orðinu líkami á Descartes hér við efnislega hluti af hvaða tagi sem er, með öðrum orðum ,allt pað sem haft getur einhverja lögun, átt sér einhvern stað og fyllt hluta rúmsins á pann hátt að par komist enginn annar hlutur fyrir“ (144). Slíkan líkama er hægt að skynja með skilningarvitunum, pað er „snertingu, sjón, heyrn, smekk eða ilman“ (144). Ennfremur getur hann „hreyfzt á ýmsa vegu, að vísu ekki af sjálfum sér, heldur parf annar hlutur að hreyfa við honum“ (144). Samkvæmt pessari skilgreiningu getur bað „með engu móti verið í eðli líkama að geta hreyft sig sjálfur, skynjað eða hugsað“ (144). Eitthvað annað verður pví að koma til sem hreyfir hann, skynjar eða hugsar.

Pannig höfum við annars vegar res cogitans sem hugsar en hefur ekki rúmtak, og hins vegar res extensa sem hefur rúmtak en hugsar ekki. Petta er hin einfalda mynd kartesískrar tvíhyggju. En málið er örlítið flóknara. Stundum er orðið líkami ekki notað í merkingunni efnislegur hlutur, heldur er pað haft um mannslíkamann í líffræðilegri merkingu, um „limavélina“ eins og pað heitir á einum stað. Slíkur líkami er af ákveðinni gerð og pótt pað sé ekki í eðli líkama sem slíks að hreyfa sig sjálfur er mannslíkaminn dæmi um líkama sem gerir einmitt pað og pví verður að halda honum aðgreindum frá líkama í hinni hreinu eðlisfræðilegu merkingu.

En par með er ekki öll sagan sögð: „Enn hafði ég nokkra ástæðu til að ætla að líkaminn, sem ég kallaði með sérstökum rétti líkama minn, heyrði mér í rauninni frekar til en allir aðrir líkamlegir hlutir“ (206). Í ljós kemur 
að einn líkamlegur hlutur er frábrugðinn öllum öðrum að pessu leyti - hann er „líkami minn“. ${ }^{31}$ Hann er sérstakur að pví leyti að Descartes getur ekki með góðu móti greint sig frá honum (á sama hátt og hann gat ekki greint sjálfan sig frá eigin hugsun). Hann getur gert greinarmun á sjálfum sér og öllum öðrum líkamlegum hlutum, en ekki pessum. Ástæðan er tilfinning hugsun - sem hann upplifir í pessum líkama vegna hinna sérstöku skynjana sem hann hefur vitund um og finnur fyrir í honum: „Ég fann til allrar lystar og geðshræringar í pessum líkama og vegna hans. Ég fann til sársauka og sældar í hlutum pessa líkama, ekki annarra“ (206). Og hann spyr í framhaldinu hvers vegna fiðringur í maganum segi honum að hann purfi að fá sér að borða og purrkur í hálsinum að hann sé pyrstur? Á pessu hefur hann engar skýringar, aðrar en pær að petta sé honum eðlislægt. Petta er eitthvað sem náttúran - ekki skynsemin - kennir honum. ${ }^{32}$

Í Hugleiðingunum hendir Descartes pví ekki bara á lofti tvö hugtök um hina hugsandi veru, hann burðast einnig með prjú hugtök um líkama. Fyrsta hugtakið á við líkama sem efnislegan hlut í almennum skilningi. Annað hugtakið á við mannslíkamann sem lífrænt eða líffærafræðilegt fyrirbæri. Priðja hugtakið á við líkama sem tilheyrir peirri veru sem skynjar og hugsar. Petta síðastnefnda hugtak er náskylt pví líkamshugtaki sem fyrirbærafræðingar á borð við Edmund Husserl eða Maurice Merleau-Ponty lögðu síðar til grundvallar ýmsum greiningum á stöðu mannsins í heiminum. Hugtökin prjú um hinn efnislega líkama, hinn lífræna líkama og hinn skynjandi líkama birtast öll í Hugleiðingunum pótt aðeins hið fyrsta sé vel skilgreint og eigi pað til að hafa sætaskipti við hin í einstökum rökfærslum.

Sambandið milli hinnar hugsandi veru og líkama af ólíku tagi er eitt meginefni „Sjöttu hugleiðingar“. Petta samband, sem er í grunninn sett fram sem fremur einfalt samband tveggja andstæðna í svonefndum ,aðgreiningarrökum“, verður í reynd býsna flókið úrlausnarefni, meðal annars vegna pess að hin ólíku hugtök um líkama pvælast hvert fyrir öðru og ekki er alltaf ljóst hvaða hugtak um hina hugsandi veru er í notkun hverju sinni. Aðgreiningarrökin (einnig nefnd „pekkingarfræðilegu rökin“) eru sett fram

31 Marion telur að hugtakið meum corpus sé hin raunverulega nýjung hjá Descartes en að samtímamenn hans (og einnig hann sjálfur að hluta til) hafi setið fastir í vef latneskra frumspekihugtaka nýskólaspekinnar og pví ekki náð að hugsa bað til enda. Sur la pensée passive de Descartes, bls. 19-21.

32 Af pessu leiðir, pótt Descartes nefni pað ekki hér, að skynjunin sem háttur hugsunar er í reynd ekki hugsunarháttur hreinnar hugsandi veru, heldur líkamlegrar veru „sem efast og skilur, játar og neitar, vill og vill ekki, ímyndar sér og skynjar“ (146). 
eftir að Descartes kveðst kominn á pá skoðun að ekki sé nein ástæða til að efast um hvaðeina pótt engin ástæða sé til að taka öllu sem gefnu (207). Meðal pess sem Descartes telur sig nú vita er að „allt sem ég skil skýrt og greinilega getur Guð gert eins og ég skil pað. Af pessu leiðir að geti skilningur minn greint einn hlut skýrt og greinilega frá öðrum, pá veit ég að peir eru aðgreindir, pví að minnsta kosti getur Guð skilið pá í sundur“ (208). Parna vippar hann sér reyndar frá möguleika yfir í veruleika: ef við getum greint hlutina í sundur með skilningnum eru peir aðgreindir í raun; vandinn er bara sá að jafnvel pótt eitthvað sé hugsanlegt er ekki par með sagt að pað sé mögulegt, hvað pá raunverulegt. ${ }^{33}$ I framhaldi af pessari forsendu setur hann fram rökfærslu sína, sem byggist á bví að unnt sé að mynda sér tæmandi hugtök um fyrirbærin. Annars vegar hefur hann „skýra og greinilega hugmynd um sjálfan [sig] sem hugsandi veru sem hefur ekkert rúmtak“ og hins vegar „greinilega hugmynd um líkama, að pví leyti sem hann hefur aðeins rúmtak en hugsar ekki“ (209). Ályktunin er svo sú að „ég og líkami minn erum tvennt ólíkt, og ég gæti vel verið til án líkamans“ (209). En tökum eftir pví að líkami sem „hefur aðeins rúmtak en hugsar ekki“ er líkami í merkingunni „efnislegur hlutur“, ekki í merkingunni „mannslíkami“, hvað pá í merkingunni „líkami minn“ sem birtist í hinni fyrirbærafræðilegu lýsingu sem rædd var að ofan og er allt annars konar líkami, líkami sem skynjar og par með hugsar. Ógild rökfærslan smýgur hér áreynslulaust á milli merkingarsviða og lesandinn fylgir hugsunarlaust á eftir.

Við verðum samt að gæta að pví í hvaða samhengi aðgreiningarrökin eru sett fram. Pau eru forsenda í lengri rökfærslu sem gengur í alveg öfuga átt við pað sem búast mætti við, pví að markmiðið er að sanna að ytri blutir séu raunverulega til. Áður, pegar óljóst var hvort skynjunin færði hugsuðinum sanninn um raunverulega tilvist hlutanna, hélt Descartes pví fram að pað að „skynja í pessum nákvæma skilningi“ væri „ekki annað en að hugsa“ (147). Hér snúast formerkin hins vegar við og hinum gagngera mun á hugsun og rúmtaki er nú beitt til að sýna fram á að tilteknar „hugmyndir“ sem eru til staðar í skynjuninni stafi í rauninni frá efnislegum hlutum sem hafi rúmtak og pað af peirri ástæðu að pær geti ekki með neinu móti átt upptök sín í hinni hugsandi veru sjálfri.

Descartes bendir á að ímyndun og skynjun séu strangt til tekið ekki nauð-

33 Sjá um petta áhugaverða ritgerð eftir Stephen Yablo, „The Real Distinction between Mind and Body“, Thoughts. Papers on Mind, Meaning, and Modality, Oxford: Oxford University Press, 2008, bls. 1-43, sem beitir háttarökfræði við að greina rökfærslur Descartes. 
synlegar hugtakinu um hina hugsandi veru, pað er fyrra hugtakinu, pví að hann geti gert sér skýra og greinilega hugmynd um sjálfan sig óháð skynjuninni og ímynduninni. Samt sem áður er hin hugsandi vera nauðsynleg fyrir skynjun og ímyndun, pví að ekki sé hægt að gera sér hugmynd um pær án hugsandi veru, enda eru pær hættir hugsunar, vitundarathafnir af ákveðnu tagi. Á hinn bóginn er ekki hægt að gera sér skýra og greinilega hugmynd um hluti sem breyta lögun sinni og hreyfast án pess að gera ráð fyrir rúmtakinu, pví að hugmyndin um rúmtak felur ekki í sér neina hugmynd um vitund eða hugsun. Til pess að skýra hvernig hlutir breytast og hreyfast í skynjuninni parf pví að gera ráð fyrir efnislegum hlutum sem hafi rúmtak.

Nú eru til fleiri eiginleikar líkamlegra hluta en hinir stærðfræðilegu, pví að peir hafa einnig til að bera „lit, lykt, bragð, sársauka og svo framvegis“ (204). Pótt ekki sé hægt að gera sér skýra og greinlega hugmynd um pessa eiginleika eru peir samt sem áður eitthvað sem ber fyrir vitundina og parfnast pví skýringar. Af peim sökum verður að skoða og athuga skynjunina, lýsa pví hvers eðlis hún er, og kanna hvort hún færi eftir allt saman sönnur á tilveru líkamlegra hluta.

Í rannsókn sinni á eðli skynjunarinnar fer Descartes, eins og stundum áđur, langar og flóknar krókaleiðir. Hann byrjar á pví að rekja hvað pað var sem hann taldi að skynjunin hefði leitt í ljós áđur en hann tók upp á pví að draga allt í efa (síðar kemur reyndar í ljós að efinn var með öllu ástæðulaus). Раð atriði sem hann nefnir fyrst er sú trú að hann hefði líkama sem hefði ýmsa hluta, til dæmis höfuð, hendur og fætur, með öðrum orðum mannslíkama. Sambandi hinnar hugsandi veru og líkamans væri pannig farið að „ég taldi líkamann hluta sjálfs mín, jafnvel að ég væri ekkert annað en líkaminn“ (204). Parna er í rauninni lýst prenns konar tengslum: (1) Hin hugsandi vera er aðgreind frá líkamanum sem hún hefur; (2) líkaminn er bluti af henni; (3) hún og líkaminn er eitt og bið sama. Ekki er gert upp á milli pessara möguleika, enda voru peir allir dregnir í efa í pví skyni að komast að pví hver sannleikurinn í málinu væri. Pessi líkami átti síðan samskipti við aðra líkama sem höfou ýmis áhrif á hann og vöktu í honum tilfinningar af ólíkum toga, pannig að hann fann til „sældar og sársauka“, hungurs og porsta, auk margvíslegra geðshreringa á borð við gleði, hryggð og reiði. Auk slíkra innri tilfinninga skynjaði hann ytri hluti og eiginleika peirra, bæði rúmtak, lögun og hreyfingu, og ýmsa ápreifanlegri eiginleika svo sem hörku og hita hlutanna, svo og „ljós, lit, lykt, bragð og hljóð“ (204-205). Hvernig á nú að útskýra tilvist slíkra tilfinninga, geðshræringa og eiginleika sem hin hugsandi vera skynjar en skilningurinn og ímyndunaraflið geta ekki útskýrt? 
Svarið felst í pví að benda á sérstöðu skynjunarinnar. Hún sker sig frá öðrum háttum hugsunar - skilningi, vilja og ímyndun - að pví leyti að hún er pað sem Descartes kallar „óvirkt afl“ (210) eða skynhæfni (passiva quaedam facultas sentiendi). Hún nemur ekkert án pess að virkt afl komi til, sem kveikir bær hugmyndir sem hún birtir. Par sem hin hugsandi vera býr ekki sjálf yfir pessu virka afli, hlýtur eitthvað annað en hún að hafa pað til að bera. Мeð öðrum orðum: hlutirnir verða að orka á skilningarvitin og vekja pannig í hinni hugsandi veru pær skynjanir eða hugmyndir sem hún hefur um líkamlega hluti. En pað gerist aðeins við nærveru likamlegs hlutar. Раð er pví á endanum skynjunin - sú sálargáfa sem var upphaflega tilefnið að efarökunum sem stigmögnuðust smám saman pangað til allt var dregið í efa - sem sannar eða sannreynir tilveru líkamlegra hluta og tengir hina hugsandi veru við hinn ytri heim. Petta pýðir að hlutirnir eru raunverulega til og orka á skynjunina og virkja hana, enda hefur hin hugsandi vera sterka, eðlislæga tilhneigingu til að telja hugmyndir sínar um efnislega hluti stafa í raun og veru frá peim sjálfum. „Líkamlegir hlutir hljóta pví að vera til“ (211). ${ }^{34}$

Раð sem Descartes sér fyrst og fremst athugavert við skynjunina er að hún er ekki nægileg forsenda öruggrar bekkingar, hún gefur ekki réttar og milliliðalausar upplýsingar um eðli og gerð efnislegra hluta. Sú mynd af hlutunum sem hún færir okkur endurspeglar ekki nauðsynlega raunverulegt eðli peirra (samkvæmt skynjuninni virðist sólin á stærð við kertisloga, en samkvæmt stjörnufræðinni er hún margfalt stærri en jörðin). Skynjanir geta jafnvel verið „efnislega ósannar“ (166) eins og skynjun hita og kulda sem eru afstæðar og skortir viðfang sem samsvarar peim nákvæmlega, en eru engu að síður raunverulegar skynjanir. ${ }^{35}$ Pað er ekki skynjunin heldur skilningurinn sem veitir okkur hina vísindalegu pekkingu, eins og Descartes hafði reyndar sýnt fram á í „Annarri hugleiðingu“ pegar hann tók dæmi af vaxmola og breytilegum eiginleikum hans eftir hitastigi. En skynjunin sannar á hinn bóginn að til séu efnislegir eða líkamlegir hlutir sem hin hugsandi vera á í gagnkvæmum samskiptum við. Skynjunin sýnir að viðfang pekkingarinnar er raunverulegt, en ekki bara hugtækt eða huglægt. Skynjunin er að vísu óljós

34 Á pað má benda að með pessum rökum hafnar Descartes allri hughyggju; skynjanirnar stafa af raunverulegum ytri hlutum, en eru ekki einberar hugmyndir, eins og írski raunhyggjumaðurinn George Berkeley (1685-1753) hélt fram á grundvelli gagnrýni sinnar á heimspeki Johns Locke (1632-1704).

35 Sbr. Lilli Alanen, „Une certaine fausseté matérielle. Descartes et Arnauld sur l'origine de l'erreur dans la perception sensorielle“, Descartes. Objecter et répondre, ritstjórar Jean-Marie Beyssade og Jean-Luc Marion, París: PUF, 1994, bls. 205-230. 
og ruglingsleg og við skynjum ekki alla hluti nákvæmlega eins og peir eru, en peir hafa samt raunverulega til að bera pað sem hægt er að skilja skýrt og greinilega. Pegar hin fyrirbærafræðilega lýsing í „Sjöttu hugleiðingu“ hefur sýnt hvert eðli skynjunarinnar er, kemur í ljós að hin hugsandi vera er pá eftir allt saman - og var raunar frá upphafi - líkamleg vera í beinni snertingu við heiminn.

\section{Sálufélag i sendibréfum?}

Pegar hér er komið í „Sjöttu hugleiðingu“ segir Descartes að „ugglaust“ sé „einhver sannleikur“ í öllu pví sem eðli hans kennir honum (211). Í kjölfarið fullyrðir hann berum orðum að sér sé engin skoðun eðlislegari en sú að hann hafi líkama (212). Hann finni til sársauka, hungri eða pyrsti. Ennfremur að pegar svo er ástatt segi eðlið honum að hann sé ekki í líkamanum eins og „sjómaður er í skipi“, heldur er hann „miklu nátengdari líkamanum en sjómaðurinn skipinu og samslungnari honum svo að við erum ein heild“ (212). Ástæðan er sú að pegar hann skynjar sársauka finnur hann til, annars mundi hann einfaldlega skilja pað, vita pað, en ekki finna neitt fyrir pví. Parna eru á ferðinni óljósar tilfinningar sem reynast „óljósir hugsunarhættir, tilkomnir af pví að hugur og líkami eru ein samslungin heild“ (212).

Pótt hann hafi rétt áður reynt að sanna eðlismun sálar og líkama með aðgreiningarrökunum, er honum núna engin skoðun eðlislægari en að hann „hafi líkama“ og að hugur og líkami séu „ein heild“. Petta virðist mótsagnakennt pangað til við tökum eftir pví að í fyrra tilvikinu var orðið líkami notað í merkingunni efnislegur hlutur en í pví síðara er átt við mannslíkama og „líkama minn“. Innri tilfinningar sýna hversu nátengd hugsunin er líkamanum, en ytri skynjun birtir fjölbreytileika hlutanna í heiminum og hinna skynjanlegu eiginleika peirra. Og hin hugsandi vera verður jafnframt fyrir áhrifum af hlutunum í umhverfinu: „líkami minn - eða öllu heldur ég allur að pví leyti sem ég er samsettur úr líkama og sál - getur orðið fyrir margvíslegum ánægjulegum eða ópægilegum áhrifum af öðrum hlutum umhverfis“ $(213) .{ }^{36}$

36 Um pessi efni sjá einnig Daniel Garber, Descartes Embodied. Reading Cartesian Philosophy through Cartesian Science, Cambridge: Cambridge University Press, 2000, og Amelie Oksenberg Rorty, „Descartes on Thinking with the Body“, The Cambridge Companion to Descartes, Cambridge: Cambridge University Press, 1992, bls. 371-392. Sjá einnig Daniel Garber, „Descartes’ Physics“ og Gary Hatfield, „Descartes' Physiology and its Relation to his Psychology“ í sama riti, bls. 286-334 og 335-370. 
Pegar Descartes ræðir hvað pað merki að skoðun sé honum eðlislag gerir hann greinarmun á prenns konar skilningi á hugtakinu eðli, pað er á (1) eðli sínu sem hreinnar hugsandi veru, (2) eðli líkamans sem náttúrufræðilegs fyrirbæris og svo (3) eðli sínu að pví leyti sem hann er „samslungin heild sálar og líkama“ (214), en pessu síðasta atriði horfði hann framhjá í aðgreiningarrökunum nokkrum blaðsíðum fyrr. Pessi heild hefur eðlislægar skoðanir sem segja honum til um „hvað heildinni sem hann er hluti af, er til góðs og hvað til ills; og til pessara nota eru pær nógu skýrar og greinilegar“ (215). Меð öðrum orðum, tilgangur pessara tilfinninga er ekki sá að veita sanna, fræðilega pekkingu á heiminum, heldur að stuðla að heill og velferð hinnar hugsandi og líkamlegu veru.

Descartes vinnur ekki frekar úr pessum premur eðlishugtökum í Hugleiðingunum. En í bréfi til Elísabetar prinsessu af Bæheimi 21. maí 1643 tekur hann upp práðinn. Hún hafði skrifað heimspekingnum til pess að fá skýringar á nokkrum atriðum sem henni póttu ekki ganga upp í umfjöllun hans um samband líkama og sálar. Hún spyr hvernig hugsun án rúmtaks gæti haft áhrif á efnislegan hlut sem hefur rúmtak, bví að öll orsakatengsl af pví tagi fælu í sér snertingu milli peirra pátta sem í hlut eiga. ${ }^{37}$ Auk pess, ef sálin ætti að geta hreyft líkamann með einhvers konar boðum pyrftu lífsandarnir að hafa vit til að skilja hvað sálin væri að fara, en pað geta peir ekki samkvæmt (hinni almennu) skilgreiningu Descartes á líkama, pví að líkami hefur að vísu rúmtak en hugsar ekki. Í bréfinu viðurkennir Descartes að full ástæða sé til að spyrja um pessi atriði, pví að pað sé tvennt sem taka purfi mið af pegar rætt er um mannssálina: „Fyrst, að hún hugsar, og síðan, að par sem hún er sameinuð líkamanum, getur hún aðhafst og polað með honum.“38 Hann kveðst „nánast ekkert“ hafa sagt um síðara atriðið, pað er í fyrri ritum sínum, pví að hann hafi verið upptekinn við að sanna greinarmun sálar og líkama. Í

37 Descartes svaraði pessari mótbáru með pví að benda á hugmyndina um pyngd sem dæmi um fyrirbæri sem verkaði á allan hlutinn án pess að bein efnisleg snerting kæmi til, en taldi reyndar að sú hugmynd væri ranglega notuð í eðlisfræði peirra tíma. Um mögulegar rætur röksemda Elísabetar af Bæheimi í Epíkúrisma, sjá Sabrina Ebbersmeyer, „Épicure et argumentations épicuriennes dans la pensée d'Élisabeth", Élisabeth de Bobême face à Descartes. Deux philosophes?, ritstjórar D. Kolesnik-Antoine og M.-F. Pellegrin, París: Vrin, 2014, bls. 171-183. Um Epíkúrisma á nýöld sjá Catherine Wilson, Epicureanism at the Origins of Modernity, Oxford: Oxford University Press, 2008. Um hliðstæður milli hugsunar Descartes og nokkurra fornaldarheimspekinga sjá Eyjólfur Kjalar Emilsson, „Hvernig Descartes er fornlegur“, Hugur 5/1992, bls. 79-99.

38 Konur í heimspeki nýaldar, bls. 36. Hér á eftir er vísað til blaðsíðutals í bókinni innan sviga í meginmáli. 
framhaldinu ætlar Descartes að reyna að skýra hvernig hann hugsar einingu peirra og hvernig sálin megnar að hreyfa líkamann.

Í pví skyni tekur Descartes upp greinarmuninn á prenns konar eðli sem hann setti fram og ræddi í „Sjöttu hugleiðingu“. Í bréfinu laumast pessi frumspekilegi greinarmunur svo lítið ber á yfir í pekkingarfræði og verður að kenningunni um frumbugmyndir (fr. notions primitives) sem öll önnur pekking byggist á. Petta eru hugmyndin um rúmtak að pví er líkamann varðar, hugmyndin um bugsun að pví er sálina varðar og hugmyndin um einingu pegar kemur að sambandi sálar og líkama. Pessum premur hugmyndum verður að halda aðgreindum, hverja peirra parf að skoða út af fyrir sig án pess að taka hinar inn í myndina. Pannig parf að skoða líkamann - hinn efnislega hlut - og eiginleika hans sérstaklega, sálina og eiginleika hennar sérstaklega, og svo eininguna út affyrir sig - án tengsla við hinar hugmyndirnar tvær. Hér eru á ferðinni pekkingar- eða skilningshættir, hugtök eða hugmyndir, um pessi fyrirbæri; ekkert er í rauninni fullyrt um verufræðilega stöðu fyrirbæranna sjálfra. ${ }^{39}$

Í bréfi frá 28. júní 1643 segir Descartes að hann hefði átt að gera grein fyrir pví hver munurinn væri á milli pessara priggja grunnhugmynda og ,athafna sálarinnar fyrir hverra tilstilli við höfum pær“ (44) en pað verður ekki skilið öðruvísi en svo að við höfum pessar hugmyndir fyrir tilstilli athafna sálarinnar, pær eru eitthvað sem skilningur okkar uppgötvar en ekki eitthvað sem við skynjum með skilningarvitunum. Jafnframt segir Descartes að hann hefði „átt að gera pað ljóst að, pó að vér vildum hugsa sálina sem efnislega (sem er í raun réttri að hugsa einingu hennar við líkamann), getum vér ekki komist hjá pví að sjá eftir á að hún er aðgreind frá honum“ (45). Samkvæmt pessu er pað að hugsa sálina sem líkamlega að hugsa einingu sálarinnar og líkamans (priðja frumhugmyndin), en samt sem áður er sálin eitthvað annað en líkaminn. Munurinn á pví hvernig við pekkjum pessar prjár ólíku grunnhugmyndir er sá að tvær peirra er unnt að hugsa með skilningnum, pað er hugmyndin um sálina (hreinn skilningur) og hugmyndin um líkamann (skilningur og ímyndunarafl). Priðja hugmyndin er annars eðlis:

[P]eir hlutir, sem tilheyra einingu sálar og líkama, [pekkjast] aðeins óljóst með skilningnum einum eða jafnvel skilningnum með aðstoð ímyndunaraflsins; en pá má pekkja mjög skýrt með skilningarvitunum. (45)

39 Lilli Alanen ræðir pessi hugtök í bók sinni, Descartes's Concept of Mind, sjá einkum bls. 44-77. Sjá einnig John Cottingham, „Cartesian Trialism“, Cartesian Reflections, Oxford: Oxford University Press, 2008, bls. 173-187. 
Hér snúast formerki pekkingarhæfileikanna við. Skynjunin, sú sálargáfa sem áður færði aðeins óljósa pekkingu, er nú orðin uppspretta mjög skýrrar pekkingar á peim hlutum sem tilheyra einingu sálar og líkama, en skilningur og ímyndunarafl, sem voru aðaluppsprettur bekkingarinnar framan af, ráða ekki við hina samslungnu heild. En jafnvel pessi umsnúningur kemur fyrir lítið:

Af pví verður pað að peir sem aldrei leggja stund á heimspeki og notast einvörðungu við skilningarvitin efast ekki um að sálin hreyfir líkamann og að líkaminn orkar á sálina; heldur telja peir hvort tveggja einn og sama hlutinn, pað er að segja peir hugsa einingu peirra; bví að hugsa eininguna sem er milli tveggja hluta er að hugsa pá sem einn hlut. (45)

Ekki er alveg ljóst hvort Descartes er að segja að hér sé eingöngu um að ræða óheimspekilega - og par með hugsanlega ósanna - hugmynd um manneskjuna, par sem pessi hugmynd byggist á hversdagslegri upplifun og reynslu, ekki ósvipað og dæmi hans af sólinni og kertisloganum. En hún virðist samt vera raunveruleg og meira en pað: eini möguleikinn á pví að öðlast pessa pekkingu er hin hversdagslega reynsla, einmitt vegna pess að hún er upplifuð og hana er ekki hægt að sanna með vísindalegum eða frumspekilegum hætti, heldur er pað fyrstu persónu sjónarhornið sem hér er í fyrirrúmi. Descartes hamrar járnið meðan pað er heitt:

Hinar frumspekilegu hugsanir sem virkja hinn hreina skilning pjóna pví hlutverki að gera oss hugmyndina um sálina kunnuglegri; og ástundun stærðfræði, sem einkum virkjar ímyndunaraflið við að skoða lögun og hreyfingu, venur oss við að mynda oss mjög greinilegar hugmyndir um líkama; og loks er pað með pví að fást einungis við lífið og hversdagslegar samræður, og með pví að halda sig frá hugleiðingum og ástundun hluta sem virkja ímyndunaraflið, að vér lærum að hugsa einingu sálar og líkama. (45-46)

Рað má kannski spyrja hvort Descartes sé full alvara með pessum orðum eða hvort hann sé að reyna að draga fjöður yfir að hann hefur ekkert svar á reiðum höndum. Hvað sem pví líður heldur hann pví fram að frumspeki, stærðfræði og hverdagsleg reynsla séu prjár ólíkar leiðir til að venja okkur við grunnhugmyndir okkar um sálina, líkamann og eininguna. Mannshug- 
urinn getur ekki hugsað hvort tveggja í senn, greinarmun sálar og líkama og einingu peirra, pví að til pess parf að hugsa pau í senn sem tvo hluti og sem einn hlut sem er ekki hægt. ${ }^{40}$ Descartes biður Elísabetu að gleyma ekki rökunum sem sanna greinarmun sálar og líkama pó að hún ætli sér að reyna að „hugsa um pá hugmynd um einingu sem hver og einn ávallt reynir í sjálfum sér án heimspekiástundunar - sem sé að pað er ein persóna eingöngu sem, á sama tíma, hefur líkama og hugsun sem eru pess eðlis að pessi hugsun getur hreyft líkamann og fundið fyrir peirri áorkan sem hann verður fyrir“" (47). Hér er komið hugtakið um persónu, sem hefur bæði hugsun og líkama og getur bæði hreyft líkamann (með viljaathöfnum) og fundið fyrir honum. Descartes fjallar ekki frekar um pessa hugmynd sína eða hvað hún kynni að fela í sér. Pess í stað flýtir hann sér að árétta að sálin sé eftir sem áður „verund aðgreind frá líkamanum“ (47). Pessar tvær eða prjár hugmyndir sem virðast í fljótu bragði útiloka hver aðra eru pví, að pví er virðist, afstæðar við ólíkar forsendur. Ein styðst við frumspekileg hugtök, önnur við stærðfræðilega greiningu, hin priðja við hversdagslega reynslu. Allar eru pær pó umfjöllunarefni heimspekinnar, sálin sem hugsun, líkaminn sem rúmtak, og heildin sem tilfinningaleg og skynræn upplifun.

Prinsessan hefur bent heimspekingnum á að „pað sé auðveldara að eigna sálinni efni og rúmtak, en að eigna henni, pegar hún hefur ekkert efni, hæfni til að hreyfa líkama og vera hreyfð af líkama“ (48). Svar hans er рað að hún megi gjarnan „eigna sálinni petta efni og petta rúmtak; pví að pað er ekkert annað en að hugsa hana í einingu með líkama“ (48). Рað kemur pví á daginn að sálin er í efninu og af peirri ástæðu má segja að hún hafi rúmtak prátt fyrir allt; pessa eiginleika hefur hún vegna náins sambands síns við líkamann. En hér er samt blæbrigðamunur á. Efnið og hugsunin eru prátt fyrir allt ekki eitt og hið sama, par er ekki samsemd á milli:

Og pegar hún hefur hugsað pað vel og reynt pað af sjálfri sér, pá verður auðvelt fyrir hana að sjá að efnið sem hún á að hafa eignað pessari hugsun er ekki sjálf hugsunin, heldur fremur að rúmtak

40 „[...] pví að mér virðist ekki að mannshugurinn geti hugsað mjög skýrt, og á sama tíma, bæði greinarmuninn á sál og líkama, og jafnframt einingu peirra; pví að til að gera pað er nauðsynlegt að hugsa pau sem einn hlut eingöngu, og á sama tíma að hugsa pau sem tvo hluti, sem er mótsögn.“ Konur í heimspeki nýaldar, bls. 47. Sú spurning hlýtur að vakna hvort Descartes sé hér kominn langleiðina í áttina að kenningu Spinoza um tvenns konar eðliseiginleika sama hlutar sem sé hvort tveggja í senn andlegur og efnislegur eða hvort hér komi í ljós að tvíhyggja hans sé í raun pekkingarfreðileg en ekki frumspekileg. 
pessa efnis er annars eðlis en rúmtak pessarar hugsunar, að pví leyti að hið fyrra er bundið við ákveðinn stað, paðan sem pað útilokar allt annað rúmtak líkama, sem hið síðara gerir ekki. (48)

Pessi orð ber væntanlega að skilja svo að rúmtak hugsunar eða sálar sem er tengd líkamanum með sérstökum hætti nái yfir efni sem fyllir rúmið par sem ekkert annað efni kemst fyrir. Petta gæti hugsunin ekki ef hún væri sjálf efnisleg í sama skilningi og efnislegir hlutir. En pað er hún ekki. Hún er eins og pyngdin, ekki öll á einum stað par sem ekkert annað kemst fyrir. Rúmtakið virðist pví tvenns konar, efnislegt og óefnislegt. Líkaminn hefur efnislegt rúmtak, en sálin eða hugsunin ekki, pótt hún nái yfir rúmtakið í einhverjum skilningi vegna sambands síns við líkamann. Petta má ef til vill skýra með dæmi úr „Sjöttu hugleiðingu“, par sem Descartes lýsir pví hvernig hann finnur fyrir sársauka í fæeti. Hin óefnislega sál, sem hefur ekki rúmtak, er ekki tengd líkamanum eins og stýrimaður í skipi, pví að hún finnur fyrir sársaukanum á ákveðnum stað - í fætinum. ${ }^{41}$ Hún er samt ekki fóturinn eða taugarnar og taugaboðin eða lífsandarnir, sem eru að verki í mannslíkamanum. Pannig er áfram eðlismunur á hugsun og líkama pótt pau séu samofin eða ein heild. „Og pannig mun Yðar hátign ekki komast hjá pví að snúa aftur til pekkingar sinnar á greinarmun sálar og líkama, pó svo að hún hafi hugsað sér einingu peirra“ (48). Pannig hverfur hugsuðurinn aftur að pekkingu sinni á greinarmun sálar og líkama pó að hann hafi hugsað pau sem einingu og heild. ${ }^{42}$

\section{Niðurlag}

Descartes er stundum hafður að skotspæni sem fulltrúi pess sjónarmiðs að maðurinn sjálfur sé hrein hugsun óháð líkamanum og öllu líkamlegu atferli: heimspekingur sem horfir fram hjá líkamanum og mikilvægi hans fyrir mannlega hugsun og upplifun. Eins og að framan er rakið væri petta mjög mikil einföldun, pótt einfaldanir séu oft vel til pess fallnar að skerpa línur í pví skyni að ná áttum í flóknum vef hugmynda og rökfærslna. Descartes á vissulega í nokkrum erfiðleikum með að takast á við afleiðingar hinnar vísindalegu heimsmyndar sem hann uppgötvar og setur fram. Pess vegna er ekki óeðlilegt

41 René Descartes, Hugleiðingar, bls. 220; sbr. Margaret D. Wilson, Descartes, bls. 207209.

42 Framhald hugleiðinga Descartes um pessi efni birtist síðan í Ástríðum sálarinnar par sem hann gerði nánari grein fyrir samspili tilfinninga og upplifunar í tengslum sálarinnar við hinn ytri heim, en of langt mál yrði að fara út í pað hér. 
pótt spurt hafi verið hvort Descartes sé að leyna raunverulegri afstöðu sinni eða hvort hann einfaldlega viti ekki hvernig hann á að takast á við vandamálin sem spretta upp af tilraunum hans til að skýra eðli manneskjunnar á grunni nýrrar vísindalegrar heimsmyndar, vandamál sem sî̉ari tíma heimspekingar tókust á við og sitja jafnvel enn uppi með. Í rauninni má segja að Descartes hafi uppgötvað sum af erfiðustu vandamálum síðari tíma heimspeki og sett fram í ritum sínum - með liprum og ljósum hætti - margar gátur sem ekki hefur enn tekist að ráða. Par á meðal má nefna spurningar sem varða samsemd (sál, líkami, heild), samband hugsunar og heilaferla, taugalífeðlisfræði meðvitundarinnar, gervigreind (vélar sem hugsa), fyrirbærafræði og vísindalega heimsmynd, femíníska gagnrýni á vestræna tvíhyggju, skynjun og tilfinningar og samband peirra við hugsunina, í stuttu máli spurningar um eðli manneskjunnar almennt séð. Svo dæmi sé tekið vekja skýringar Descartes á sambandi rúmtaksins og hugsunarinnar snúnar spurningar um samsemd. ${ }^{43}$ Ef líkaminn hugsar með einhverjum hætti, eins og lýst er í Orðræeðuni, og hin hreina hugsandi vera hugsar með skilningi sínum og vilja, eins og hún virðist geta gert í Hugleiðingunum, og samsetning peirra - hinn sanni maður - hugsar líka, eins og hún virðist gera samkvæmt bréfunum, pá virðist komið upp vandamál sem kennt hefur verið við „of marga hugsuði“ (e. the problem of too many thinkers) ${ }^{44}$ Hver er pað eiginlega sem hugsar og hvað er hugsun? Í ritum Descartes birtist breytileg afstaða til slíkra vandamála sem virkar stundum eins og undanbrögð eða ólíkir varnarleikir við gagnrýni af mismunandi tagi, en vera má að hér sé ekki síður merkingarvandi á ferðinni, til dæmis að hugtökin prjú um líkama renni á stundum fullmikið saman. Descartes lítur á manninn sem samstofna við heiminn, sem „veru-í-heiminum“, en pó með sérstöðu. Hann setur fram nýjan skilning í vísindum og heimspeki, en styðst við ýmis hefðbundin hugtök úr aristótelískri nýskólaspeki, flækist svo sjálfur í hugtakavefnum og smýgur milli merkingarsviða. Hann hvarflar milli pess að segja að hann sé hrein hugsandi vera, að hann sé vera sem er samslungin heild líkama og sálar, yfir í að hann sé nánast líkamleg vera eingöngu; svo og milli

43 Um pessi efni sjá til dæmis áðurnefnd rit eftir Damasio, Descartes's Error; Clark og Chalmers, „The Extended Mind“; eða Mikael Karlsson, „Do We Think With Our Brains?" og „Action, Causation \& Description“, A Explicação da Interpretação Humana, ritstjóri João Sáagua, Lissabon: Edições Colibri, 2016, bls. 313-325.

44 Sjá til dæmis Eric T. Olson, „Personal Identity“, The Stanford Encyclopedia of Philosophy, ritstjóri Edward N. Zalta, á vefslóðinni https://plato.stanford.edu/ archives/fall2019/entries/identity-personal, og tilvísanir par; sbr. einnig Steinvör Pöll Árnadóttir, „Functionalism and Thinking Animals“, Philosophical Studies. An International Fournal for Philosophy in the Analytic Tradition 147: 3/2010, bls. 347-354. 
líkama sem efnislegs hlutar og lifandi líkama sem er líkami hans sjálfs, sem er persóna sem hefur bæði sál og líkama, eða er ein óskiptanleg heild, er sannur maður en hvorki hreinn andi né einber vél. Ferlið er allt að pví díalektískt: Fyrst, í Orðr๔ðunni, er pað mannslíkaminn, nánar til tekið heilinn, sem hefur hugmyndir og hugsar par með í einhverjum skilningi - en án skynsemissálar. Síðan, í Hugleiðingunum, einkum pó framan af, er pað hin hugsandi vera sem hugsar - án líkamans, að hún heldur. Loks, undir lok Hugleiðinganna og í bréfunum, sameinast pessar tvær andstæður í einni heild sem er hvort tveggja í senn, líkamleg og hugsandi vera, sem er í rauninni í fullu samræmi við pá skoðun hans strax í Orðreðunni að „sannur maður“ sé hvort tveggja í senn, andleg og líkamleg vera, en ekki annað hvort. Рað er pessi skoðun sem fer gjarnan forgörðum pegar myndin sem máluð er upp af heimspeki Descartes er einfölduð úr hófi fram.

\section{ÚT D RÁT T UR}

Descartes er oft talinn fulltrúi pess sjónarmiðs að maðurinn sé hrein hugsandi vera, óháð líkamanum. Í pessari grein er íslenskum lesendum kynntur andstæður lestur á Descartes, sem rekja má til fyrirbærafræðilegrar greiningar heimspekinga á borð við Lilli Alanen og Jean-Luc Marion á verkum hans, par sem hin líkamlega vídd er í fyrirrúmi. Með pví að rýna nokkra lykilkafla og rökfærslur úr Orðreðu um aðferð, Hugleiðingum um frumspeki og bréfaskriftum Descartes við Elísabetu af Bæheimi má sjá að í umfjöllun hans koma fram prjú hugtök um líkama, fyrst hinn efnislegi hlutur, síðan mannslíkaminn og svo pað sem Descartes kallar „líkama minn“ sem hann getur ekki aðgreint frá sjálfum sér frekar en eigin hugsun. Fyrirbærafræðileg lýsing hans á ytri og innri skynjun sýnir að hin hugsandi vera er jafnframt líkamleg vera sem hefur tilfinningu fyrir sjálfri sér og heiminum. Ýmis vandkvæði eru samt sem áđur á greiningu Descartes og spurning hvort tvíhyggja hans sé, pegar öllu er á botninn hvolft, frekar pekkingarfræðileg en frumspekileg. Milli ritanna priggja, sem hér er fengist við, má sjá eins konar díalektískt ferli: í Orđređunni hugsar mannslíkaminn í einhverjum skilningi, í Hugleiðingunum hugsar hin hugsandi vera, í fyrstu án líkamans að pví er virðist, en undir lok Hugleiðinganna og í bréfunum sameinast pessar andstæður í einni heild sem er hvort tveggja í senn, líkamleg og hugsandi vera, sem er í fullu samræmi við upphaflega skoðun Descartes í Orðreðunni að „sannur maður“ sé allt í senn, hugsandi og líkamleg vera sem hefur bæði kenndir og tilfinningar.

Lykilorð: Descartes, tvíhyggja, fyrirbærafræði, líkami, skynjun, hugsun 


\section{A B S T R A C T}

\section{Pure Mind or Real Man: Descartes on the Bodily Aspects of Thought}

Descartes is often considered to have advocated the view that man is a pure thinking being, independent of the body. This article introduces Icelandic readers to a different reading of Descartes derived from phenomenological analysis of his works by philosophers such as Lilli Alanen and Jean-Luc Marion, focusing on the bodily dimension. A close reading of key passages and arguments of the Discourse, the Meditations and the correspondence between Descartes and Elizabeth of Bohemia reveals that Descartes uses at least three concepts of the body; as a material thing (a physical object), as the human body and as what Descartes calls "my body" from which he cannot distinguish himself any more than from his own thinking. His phenomenological description of internal and external perception demonstrates that the thinking being is equally a bodily being that is in the possession of a sentiment of itself and the world. However, Descartes's analysis presents various difficulties, and raises the question whether his dualism is after all epistemological rather than metaphysical. A dialectical process can be observed between the three writings studied: in the Discourse the human body thinks in some sense, in the Meditations the thinking being thinks, first apparently without the body, but towards the end of the Meditations and in the letters these oppositions are united in one whole that is both a bodily and a thinking being, a view that is in accord with the original view of Descartes in the Discourse, that the "real man" is both a thinking and a bodily being that has both feelings and emotions.

Keywords: Descartes, dualism, phenomenology, body, perception, thought

\section{Gunnar Á. HarĐarson}

Prófessor í heimspeki

Sagnfræði- og heimspekideild

Hugvísindasviði Háskóla Íslands

Sæmundargötu 2

102 Reykjavík, Ísland

gunhar@hi.is 
